WellBeing International

WBI Studies Repository

2010

\title{
Discourse and Wolves: Science, Society, and Ethics
}

William S. Lynn

Williams College

Follow this and additional works at: https://www.wellbeingintlstudiesrepository.org/acwp_habr

Part of the Animal Studies Commons, Comparative Psychology Commons, and the Other Anthropology Commons

\section{Recommended Citation}

Lynn, W. S. (2010). Discourse and wolves: Science, society, and ethics. Society \& Animals, 18(1), 75-92.

This material is brought to you for free and open access by WellBeing International. It has been accepted for inclusion by an authorized administrator of the WBI Studies Repository. For more information, please contact wbisr-info@wellbeingintl.org.

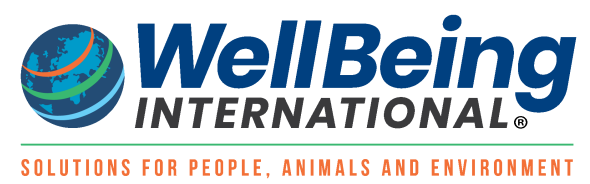




\title{
Discourse and Wolves: Science, Society, and Ethics
}

William S. Lynn

Williams College

\section{$\underline{\text { KEYWORDS }}$}

discourse, ethics, hermeneutics, wolves

\begin{abstract}
Wolves have a special resonance in many human cultures. To appreciate fully the wide variety of views on wolves, we must attend to the scientific, social, and ethical discourses that frame our understanding of wolves themselves, as well as their relationships with people and the natural world. These discourses are a configuration of ideas, language, actions, and institutions that enable or constrain our individual and collective agency with respect to wolves.
\end{abstract}

Scientific discourse is frequently privileged when it comes to wolves, on the assumption that the primary knowledge requirements are matters of ecology, cognitive ethology, and allied disciplines. Social discourse about wolves implicitly challenges this privilege and provides a rich array of social perspectives on human-wolf relations. Ethical discourse has until recently lagged behind the other two. So too, ethicists are increasingly challenging the adequacy of scientific and social discourse. They do so by calling attention to the value-laden character of all discourse, and the unavoidable ethical questions that confront us as we learn to share the landscape with large predators like wolves.

In early July of 2006, Suzanne Stone and her daughter, Sierra, drove to the Sawtooth National Forest to search for an orphaned group of eight-week-old wolf pups. The Stones drove there after hearing that Wildlife Services, an arm of the U.S. federal government, had killed the parents-a male and female from the Big Water Pack in the Soldier Mountains_and left the pups to die from starvation or predation.

I have known Stone a long time, and she is neither a stranger to, nor an opponent of, lethal "wolf control." As the Northern Rockies representative of the nonprofit organization Defenders of Wildlife, she works with citizens, scientists, the livestock industry, and government officials to manage the growing wolf populations of the western United States. Part of her work involves administering one fund that compensates ranchers for livestock or working dogs lost to confirmed wolf depredation, and another fund 
that subsidizes proactive measures to avoid or mitigate conflicts between wolves and people. Stone is a sympathetic voice for ranchers and rural communities in wolf country, and she realizes that killing wolves is at times an unfortunate necessity. I should note that I agree with her. And still, she was disturbed enough to search throughout the day and into the night for the pups. She never found them. Neither did Wildlife Services, which, hoping to take the edge off a public relations disaster, also went looking for them.

An interesting contrast to Stone's attitude was that of Steven Nadeau of the Idaho Department of Fish and Game. He authorized the killing of these wolves because they were believed to have preyed on livestock. In comments to National Public Radio, he said, "The regrettable loss of a few pups does not have any real biological impact on the recovery or long-term viability of this population [of wolves]" (Shogren, 2006). Nadeau is almost certainly right about the biological effect of the loss of these pups. Pups have always been particularly vulnerable to disease and predation, and the reproductive cycle of wolves is adapted to high pup mortality. The loss of a few pups will have little, if any, impact on the population biology of wolves in Idaho. But I do not think this is why the story made the news. Rather, it was the contrast between Stone's concern and Nadeau's apparent indifference that captured the attention of the public in the United States and Canada. And in this contrast there is much to be learned about the scientific, social, and ethical discourses that inform humanity's troubled history with wolves across the globe.

I want to explore this contrast, not by focusing on Stone and Nadeau per se, but by probing the discourses that inform our thoughts, actions, and policies toward wolves. I will do this in three steps. First, I will outline the concept of discourse in terms of its meaning in hermeneutics. I will then explore the dominant discourses that inform the human relationship with wolves-discourses that are rooted in science, society, and ethics. I will finish by examining the theoretical, methodological, ethical, and interdisciplinary consequences of taking discourse seriously.

\section{Methodological Caveat}

As you read this article, you will note that it does not conform to the usual conventions of scientific literature. One might expect this, as I do not pretend to be a scientist in the usual sense of the term. But there is more to it than that. The standard conventions of scientific articles-a statement of the research question, justified by a literature review of findings to date, a description of the methods and measures used to test a hypothesis, and a discussion of the results, their significance, and possible avenues for future exploration-are entirely appropriate to research questions amenable to quantitative methods. These conventions were developed in and for the natural sciences, work well within those domains, and overall there is no reason to disparage them (Lynn, 2004; Chalmers, 1999; Lindberg, 1992).

When it comes to explaining human beings and their societies, there was a time when the human sciences sought to ape the natural sciences in theory, method, and publishing conventions. This was a dismal failure, and, while the struggle to shift gears continues, the positivist turn is long dead. The reason is that human beings do not conform to the models of determinism and/or predictivism that are the hallmarks of the physical sciences. The sentience and sapience of people-their awareness and selfawareness-make their thoughts and actions contingent and creative, transcending the boundary conditions for which the research practices and writing conventions of the natural sciences were devised (Bernstein, 1991; Rorty, 1979). Yes, there are still people who defend a "naturalistic model" of the human sciences. Yet it is embarrassing to see old-school positivist scholars chopped up by their peers because they have not kept up with the history and philosophy of science literature over the last fifty years. E. O. Wilson and his acolytes of consilience best represent this yearning for the old ways (Westley \& Miller, 2003; Wilson, 1998). We can do much better than this now. 
What is needed in such cases is a methodology adapted to the "human sciences," something capable of causal explanation (the hallmark of science) without the pretense of determinism or predictivism. ${ }^{1}$ Various social theories and qualitative methodologies have arisen to fi II this need (Schwandt, 2007; Hesse-Biber \& Leavy, 2005; Denzin \& Lincoln, 2000). So too have new conventions for publications, specifically around the idea of interpretation and narrative (Yanow, 1999; Fischer \& Forester, 1996; Roe, 1994). So for those with an interest in methodological affairs, what follows is an interpretation of several discourses that inform how we think about and act toward wolves. Intentionally broad in scale and scope, it looks for the resonance between our ideas, behavior, and social institutions, or, to put the matter in social theoretical language, the interplay of human agency and social structure. The point is not to predict or determinatively explain what people and organizations do. That is not possible with human and some other beings. Rather, the purpose is to reveal the discursive dynamic that constitutes, at least in part, our individual and collective stance toward wolves in the world. ${ }^{2}$

\section{Discourse}

I approach discourse as a hermeneuticist. Hermeneutics is the study of understanding, one of the main perspectives in social theory. ${ }^{3}$ The basic idea is that our personal and social lives can only be fully understood when we account for the meaning embedded in our actions and social relations, such as is found in our presuppositions and worldviews. To explain the human world, we therefore have to interpret what people mean when they say or do something, and what significance their words and actions have for the rest of the world.

Engaging in this kind of interpretation might seem trivial to some, as if picking someone at random on the street and asking them about wolves is going to tell us the truth about wolf biology or ecology. But that would be missing the point. Hermeneuticists are interested in our individual and collective interpretations of wolves. These interpretations are highly significant, if, let us suppose, politically motivated wildlife professionals foster an approach to environmental policy that emphasizes agricultural production, ranching, and sport hunting at the expense of predators, ecosystem function, and biodiversity. So one cannot understand (as in, describe, explain, evaluate, or justify) why someone or some group acts as they do without first interpreting what they think and how it informs their actions. It is for this reason that hermeneutics is a keystone tradition of scholarship with respect to the theory and methodology of the human sciences (Wachterhauser, 1994; Gadamer, 1993; Bruns, 1992; Mueller-Vollmer, 1989).

To the hermeneuticist, discourse refers to the interconnections between ways of thinking and acting. It is not only a point of view that helps direct our actions in the world; it is also the meaning(s) embedded in our actions and social institutions. This approach extends the idea of discourse beyond the expression of an idea or perspective, whether in speech, writing, or artistic creation. It focuses on the role of language in the formation of presuppositions, worldviews, and ways of life. In this extended version, discourse traces the linguistic connections between several components-thought, action, and social institutions. The argument from a discursive perspective is that language interweaves these components in such a manner that they are reciprocally constituted and/or mutually informing. That is to say, there is an inextricable linkage between how individual and collective agents think, speak, act, and interact.

I use the term resonance (or resonances) to refer to the linkages between the components of discourse, as well as between different discourses themselves. I say resonance because these linkages are not uniform or static, but plural and shifting. They do not constitute a system of discrete inputs and outputs amenable to modeling and prediction. Rather, they are a shifting configuration of meaning and social interaction that must be apprehended for their causal influences. 
This contingency of meaning and social interaction arises from the way in which discourse connects intangible and tangible phenomena. ${ }^{4}$ There is an ecology of intangible ideas, intentions, worldviews, and culture informing more tangible actions, social institutions, and their outcomes (e.g., environmental and social policy). This ecology defies reductionism and is better understood through a process of interpretation. Discourse is a powerful conceptual tool in the process of social and moral interpretation. It helps us identify and theorize a shifting field of resonances, and thereby understand the context, content, and consequences of a discourse. With this in mind, we can better understand why and how an idea, social practice, or institution exists, operates, and perpetuates itself (Kelly, 1990). ${ }^{5}$

Discourse may simultaneously exist at several levels. At one level are ideas, whether expressed in terms of reasons or emotions. At another level are actions. Here, reason and emotion become the motivating factors for acting in the world. At still another level are social institutions such as government agencies, economic and politically-based interest groups, or nonprofit advocacy organization. These institutions are also part of our discourses, patterns of thinking and acting that, over time, take on concrete and durable form (Wolf, 2003b; Barnes \& Duncan, 1992; Ball, 1988). When Stone expressed care for the well-being of abandoned wolf pups, her expression was at the discursive level of ideas. When she took to the field to find and save the pups from starvation, her behavior was at the action level of discourse. When she went back to work at an NGO that is part of our social system, she was involved at the institutional level of discourse.

If we think of a discourse as a text, such as an essay or a policy statement, then we can "read" these texts for their meaning(s). Like a written or spoken narrative, the meaning of a discourse can be interpreted for its good or ill intentions, content, implications, and consequences (Ricoeur, 1996, 1991, 1977). Thus, when the state of Alaska justifies the aerial gunning of wolves through policy statements of dubious scientific value, we have a discourse we can read like a text and from which we can extract its meaning. So too, when gunners take to the air to kill wolves, we have an equally meaningful action on which to base our interpretations and from which to discern the values and worldviews that inform those actions. When the Alaska Board of Game continues to authorize lethal control measures against wolves, we see a social institution whose members, policies, and practices are partaking of a broader antiwolf discourse.

Interpretations of discourse are never perfect or unequivocal. There is always more to be learned, and multiple meanings are the norm. Nor are the intentions behind, or the consequences of, a statement or act always obvious or explicit. They can be concealed, poorly understood, or unexpected (Hirschman, 1987; Hirsch, 1967). Because of this and other contingencies, hermeneuticists are humble about the power of any one interpretation and encourage dialogue to generate a broadly shared horizon of understanding. Moreover, they believe that reason and evidence, along with goodwill and a skeptical eye, can distinguish better from worse interpretations. In this way, we make progress in finding the truth. Finally, truth is not relative or absolute. In alignment with the best understanding of science, truth is always proximate. While veracity is the goal, verisimilitude is the reality. For hermeneuticists, understanding is always partial and fallible, and it is through dialogue with others that we reach a deeper and better understanding of the presuppositions and worldviews of ourselves and others. ${ }^{6}$

\section{Three Types of Discourse}

We are now in a position to examine how discourse influences our relationship with wolves. But which discourse should we examine? Because discourse lives and grows in our thoughts, actions, and social institutions, and because we know that discourses are not monolithic, there are many possibilities from which to choose. Nonetheless, when we think about public policy and the debate over wolves, scientific, 
social, and ethical discourses are particularly important. They have a disproportional influence on how we view and relate to wolves (and other creatures) the world over.

Scientific Discourse. The first discourse is that of the natural sciences, particularly ecology, ethology, and evolutionary biology, as well as their applied siblings in wildlife management and conservation biology. This is not meant to be a definitive list. Rather, it illustrates the range of basic and applied sciences with a claim to knowledge about wolves. Overall, scientists are attempting to study nature's wolf-the Grey wolf (Canis lupus), Mexican wolf (Canis lupus baileyi), Red wolf (Canis rufus), and Ethiopian wolf (Canis simensis)-all members of the dog family, Canidae.

While I cannot do justice to the significant contributions made by scientific discourse, allow me to note the dynamic nature of this knowledge. For example, new methods in genetics are revealing that wolves have a more complex natural history than we had previously believed. We have long understood that wolves are related to domestic dogs (Canis lupus familiaris), the dingo of Australia (Canis lupus dingo), and other canids such as the coyote (Canis latrans) of North America or the Golden jackal (Canis aureus) of Africa and Eurasia. Nevertheless, new information continues to alter our assessment of the evolution of the dog family and its subsequent speciation. For example, there is some evidence of a newly discovered species in eastern Canada, Canis lycaon, the eastern wolf (Kyle et al., 2006).

Many members of the scientific community, advocacy groups, and the wider public believe natural science is a privileged discourse about wolves. Thus, to study wolves, one must necessarily be interested in their evolution, ecology, ethology, management, or conservation. This orientation is understandable. The natural sciences are indispensable to our knowledge of wolves, and we should not dismiss what such science can teach us.

We should recall, however, that, while necessary, the natural sciences are neither infallible nor sufficient in and of themselves. For instance, scientists now recognize wolves as highly skilled carnivores-top predators in their many habitats-with an overall effect of promoting biodiversity (Smith, Douglas, Petersen, \& Houston, 2003). This was not always the case in scientific circles. It took over a century (from the mid-1800s to the mid-1900s) for scientists to shed their view of carnivores as parasites on the rest of nature (Dunlap, 1988; Worster, 1985). Some believe this ideology still guides the efforts of U.S. federal agencies like the curiously named Wildlife Services (Robinson, 2005). Indeed, at a time when wolves and other predators were widely reviled both within and outside the scientific community, it fell to a few with courage to challenge this ideology, pointing to the valuable ecological roles of predation. Aldo Leopold's "Thinking like a Mountain" is the story of one such scientist and his growing appreciation for the ethical and ecological value of all nature's creatures (Flader, 1994; Leopold, 1968).

Moreover, there is an interesting and emergent literature that attempts to explore the "human dimensions" of wildlife management. This literature is in part an outgrowth of wildlife management's self-recognition that the natural sciences are never enough to understand either human-animal relations, or environmental policy as it impacts wildlife. Much of this literature invests itself in the trappings of natural science, however, with an emphasis on quantification, prediction, and control. Human beings become another "variable" to be managed, using the scientistic theories and methods of what is loosely called the social sciences, or more accurately the behavioral sciences. Values, including moral values, become individualist preferences to be managed by technocratic elites for the highest material or political return. For reasons noted in the methodological caveat above, this scientistic approach to human dimensions is problematic at best (see Manfredo, Vaske, Brown, Decker, \& Duke, 2009; Decker, Brown, \& Siemer, 2001; Gray, 1993). 
So it implies no disrespect to science or scientists to note that science is only one discourse among many. We cannot abstract science from the social context in which it is practiced. Moreover, science is never enough to tell us everything we need to know about wolves. If we want a fuller appreciation of what wolves mean, and how this informs our individual and collective agency toward them, then we will have to step beyond science and explore other discourses.

Social Discourse. Alongside the natural sciences, there is a wide-ranging set of social discourses about wolves. These discourses are articulated in the human sciences, the arts and humanities, as well as in popular culture. ${ }^{7}$ They emerge out of the dynamics of human society, and take many complex forms. They embody divergent interpretations of wolves — who they are, what they do, and why they do it-and how human beings should respond to them.

A catalogue of these interpretations has never been assembled, but from diverse sources we know the wolf has been interpreted as a teacher of hunting skills; an attentive parent; an exemplar of courage; a loyal pack member; a fellow creature; a spirit guide; a competitor for game; a depredator of herd animals; a symbol of strength, cunning, and power; a fool driven by gluttony; a cowardly opportunist; a villain, varmint, and vermin; an agent of the devil; the Devil himself; a threat to the safety of other wildlife; a parasite; a stalker of children and the elderly; a paragon of wildness; and the irrepressible spirit of women, to name a few. Such passionate interpretations are evident in any wolf conference one cares to attend. A simple Google search on "wolves" returns an abundance of Web sites extolling or condemning wolves as a source of inspiration or fear, symbolizing the best and worst of human traits. The human fascination with wolves has produced perhaps the largest wildlife-related literature in the form of calendars, photographs, coffee table books, and other popular media (selections from this literature include Coleman, 2004; Dutcher \& Dutcher, 2002; Borchardt, 1998; Evans, 1998; Matteson, 1996; McIntyre, 1996; Busch, 1994; Douglas, 1992; Brandenburg, 1990; Lopez, 1978).

Wolves are particularly symbolic animals: they stand in for something else happening in human society. Thus, wolves may symbolize the endangered species or wild landscapes that people believe should be protected or exterminated. They may become flashpoints of political tension between branches or levels of government, regulatory agencies, or corporate and nonprofit pressure groups. Wolves may be seen as exemplifying the threats to rural economies, or the prospect of economic growth and diversification in the form of ecotourism. They may represent the loss of political control by established communities of "insiders" and the garnering of political power by new communities of "outsiders." They may be associated with an oppressed social group, like the First Nations. Conversely, oppressed people may see wolves as fellow travelers and stand in solidarity with their well-being. This symbolic, values-laden, politically charged aspect of human-wolf relations has been eclipsed over the years. There is, however, a burgeoning literature on wolves and public policy that is not only excellent, but is beginning to redress this imbalance (Robinson, 2005; Nie, 2003; Lynn, 2002; Rawson, 2001; Sharpe, Donnelley, \& Norton, 2001; Mclntyre, 1993).

Ethical Discourse. Of all the discourses over wolves, ethics is the least acknowledged. When wolves are the subject of explicit ethical thought, they tend to be used as portals to other arguments and issues, such as ecological restoration, ecological integrity, or value conflicts in environmental politics (see Katz, 2000). Comparatively little consideration is given to their wellbeing in and of themselves, either among philosophers or policy-makers. Yet implicit moral sensibilities influence scientific and social discourses and make wolves the object of much normative speculation. Resolving this tension between explicit ethical thought and implicit moral presuppositions requires more attention to the ethical discourses of human-wolf relations. 
Ethics is one of the most pervasive discourses in human history. We are, in the words of Mary Midgley (1995), the "moral primate," a species with a propensity to understand our world in moral terms. Questions about what is right, good, just, or of value are ubiquitous in all human societies. This is not because individuals or groups agree on a single ethical worldview. The range of ethical perspectives is quite broad, and scholars disagree on whether moral norms are entirely relative to personality or culture (i.e., subjective and cultural relativism, respectively), objective truths based on analytic reason (e.g., Kant and the traditions of analytic philosophy), the by-product of divine commands (e.g., Christian or Islamic ethics), or situated judgments based on reason, evidence, and context (e.g., casuistry, hermeneutics, practical ethics). In spite of these differences, there is no denying that we humans give extraordinary power to moral norms in our personal and social affairs (Midgley, 1995, 1993b; Rachels, 1986). ${ }^{8}$

In terms of ethics and wolves, there are several sources that should be highlighted. Arne Naess uses deep ecology to examine the ethical conundrums involved in conflicts between predators like wolves and bears, and the herding communities of Norway (Naess, 1974). Midgley discusses how wolves (and other predators) are the symbolic substitutes onto whom we transfer the guilt, fear, and loathing of our own destructive propensities (Midgley, 2001). Ashby Sharpe does a fi ne job of teasing out and making explicit the ethical content in a series of articles and presentations on ecological restoration in the Adirondack region of New York, (Sharpe et al., 2001). Robert Jickling and Paul Paquet (2005) explore the assumptions about science and management involved when wolves are considered from an ethics-based epistemology, in contrast to the dominant science-based epistemologies. Jody Emel (1995) has explored our moral relationship to wolves through the lens of ecofeminism and geography. My own work has focused on the need for both sound science and sound ethics, the role of discourses about wolves in pulling nature and culture into a common orbit of ethical meanings (termed "cosmopolitanism"), and the way in which the well-being of wolves in the landscape is a dual sign of environmental and moral health (Lynn, 2007b, 2005, 2002, 1998a, 1998b).

We may be in the midst of a "moral turn" regarding discourses about wolves. Since 1998, both Defenders of Wildlife and the National Wildlife Federation have held a series of conferences in which the ethics of wolf recovery played a significant role. Building on the momentum of these conferences, the World Wolf Congress of 2003 (held in Banff, Canada) was something of a watershed. Alongside a substantial session that featured the ethics of wolf recovery, ethics was a subject of concern in many of the plenaries, paper sessions, and dinner conversations. The importance of this moral turn was driven home by the concluding address, delivered by David Lavigne, senior science advisor to the International Fund for Animal Welfare. In his talk, Lavigne emphasized the ethical and value-laden dimensions of wolf recovery and management. His overall point was not that science is unimportant. To the contrary, science is indispensable in describing and explaining what is occurring with wolves in nature or in specifying the factual basis of human-wolf conflict. Yet in spite of its descriptive and explanatory power, science cannot make moral decisions for us about how we ought to live with wolves. Such policy questions can only be answered with explicit reference to ethical norms. (For elaborations on this speech, see Lavigne, 2006.)

Subsequent meetings on ecological sustainability (held in Limerick, Ireland in 2004) and, shortly thereafter, Carnivores 2004 (held in Santa Fe, New Mexico), featured well-attended sessions on the role of ethics in wolf recovery, wildlife conservation more broadly, and sustainability in general. Time will tell if this moral turn represents something of sustained interest to the wolf community.

\section{Discursive Consequences}

Discourses are consequential. They help shape how we see and act in the world, at both individual and collective levels. The idea of discourse, as opposed to a discourse itself, is equally significant, for it makes possible the disclosure of the meaning, power, and interaction of one or more discourses. If we did 
not have the idea of discourse, we would not be able to identify the nexus of beliefs and behaviors that constitute distinct discourses. With this observation in mind, I want to conclude by noting four consequences of discourse as it affects the world of wolves.

The first consequence is that discourse has a substantial impact on our theoretical approaches to humanwolf relations. An attention to discourse helps us identify which theoretical perspectives are (and are not) being advanced when the discussion turns to wolves. This is crucial when various positions argue that theirs is the "truly" objective, reasoned, evidenced, and scientific point of view. We should be skeptical of such claims by now, but many are still bamboozled by such rhetoric. The promotion of the International Wolf Center as an institution providing "unbiased" information about wolves serves as one example. Sailing under the flag of value-neutral information, its rhetoric obscures a science-based discourse that is the subtext to its education and outreach initiatives (Anonymous, 2006).

Aside from sharpening our theoretical vision, a discursive approach also implies that we are always theorizing our relationship to wolves. I say "theorizing" to emphasize that, whether our theories are hunches, testable propositions, or expansive worldviews, they are always fallible, contestable, and in the making. Theorizing wolves is an ongoing activity, an endeavor of heart and mind and practice that will never be fully settled. As we deepen our knowledge of wolves, as our social and moral norms shift and conflict, as the plight of wildlife and wild landscapes becomes increasingly acute, our theories will evolve as well. If the history of ideas is any guide, such an evolution will not be gradual and unilinear, but punctuated by conflict and increasing diversity (Livingstone, 1992; Kuhn, 1970; Glacken, 1967).

The impact on methodology is the second consequence, and equal in scope to that of theory. Sit in on a wolf conference, and one quickly discovers the importance of numbers. Quantification is a touchstone of most presentations, whether they are from advocates, managers, politicians, and/or scientists. What distinguishes them is their skill and the purpose of using these numbers, not the emphasis on quantification itself. For the reasons outlined above, discourses cannot be studied using the techniques of the natural and resource sciences so familiar to wolf biologists-radio and global-positioning collars, mathematical modeling, genetic testing, etc. To plumb the depth and power of a discourse requires qualitative, not quantitative, methods-interviews, participant observation, documentary analysis, etc. This may be a hard pill for some to swallow, as these methods employ a set of ideas and practices that are very different, and in some cases highly critical of, the natural science model of research.

A third consequence is the role of ethics as a form of discursive power. Ethics can focus our attention on the moral values at stake in a social or political issue and provide guidance for our thought and action in addressing moral problems. As important, ethics is indispensable for holding people and societies accountable for their (un)ethical actions, something that should not be confused with legal culpability. Ethics is the foundation for all movements of social change, whether these are for animal, environmental, or social causes. Generally, these movements involve a twofold process of critique and vision. They criticize habits of thought as well as individual and social practices that negatively impact our own wellbeing, as well as that of others. At the same time, they envision a way of life that promotes our own wellbeing, as well as that of others (Moyer, Macalister, Finley, \& Soifer, 2001; Sibley, 1970).

Of course, our moral concern for others is not restricted to Homo sapiens. Our moral community is a mixed one, comprising humans and nonhuman animals. We all share an intrinsic value and moral standing alongside the rest of nature, albeit at different individual and collective scales, something that requires contextual nuance in our ethical reasoning. Nonetheless, people, animals, and nature all possess a potential well-being that ethics helps us appreciate and protect (Fox, 2001; Midgley, 1998; Rolston, 1988). 
The fourth consequence is the recognition that bias haunts our research into, policy regarding, and management of, wolves. This bias is not one of invidious distortion, but of an imbalance of discourse. To begin with, the natural sciences are overrepresented in the conversation. Over the years, other fields of learning have weighed in, but these are still underrepresented when it comes to setting policy and management goals. Note that this is not a failure on the part of the individuals, per se. It is rooted in the dominant discourses of the social community that concerns itself with wolves. Redressing this imbalance will require expanding the kinds of discourses we routinely take into consideration.

We can take steps to redress this situation by developing a truly interdisciplinary learning community around the subject of wolves. This is easier said than done, but there are some excellent models where this has worked. One is the Ethical, Legal and Social Implications of Research (ELSI) program associated with the Human Genome Project. Lasting from 1990 to 2003, the project sought to sequence the genome of humanity. This was "big science," very expensive and highly technical, and in the domain of the life sciences. Even so, the need to look at ethical, legal, and other social issues was recognized early and ELSI-based research was integrated with genomic science throughout the project. ${ }^{9}$ Such an approach might work for wolves. This would require a shift from depending on individuals to self-organize presentations, papers, articles, etc. on ethical and other issues regarding wolves, to advocacy and scholarly organizations proactively integrating ELSI-like content into conferences, journals, and other organs of research and outreach.

\section{Final Thoughts}

I think it is clear that we need to take a broad range of discourses into account if we are going to better understand and manage humanity's relationship with wolves. Welcoming these discourses to a common table will require an interdisciplinary spirit, as noted above. So I want to conclude by emphasizing the need for interdisciplinarity. A landscape analogy may help make this point.

Imagine that a valley surrounded by three mountain ranges represents the study of wolves. The mountains to the north are the Ethics Range, to the southeast, the Social Range, and to the southwest, the Science Range. Members of the wolf community sit atop each range and have a view of the wolves in the valley below. They can also see each other and might wonder what the others can see that may be invisible to them.

With this metaphor in mind, we can say that each group has a different point of view on the world before them and a distinct outlook from which to derive insights on wolves. When the community gets together to talk about their observations, they converse in ways that reflect the insights developed from their particular viewpoints. This might include what they think can, should, or ought to be done to manage humanity's relationship with wolves. They are in effect speaking in terms of distinct discourses. By proactively considering each point of view, they share insights that may not have been clear or even visible to the others. They cross-check, contest, confirm, and create a deeper and broader understanding of wolves.

In practical ethics, hermeneutics, and qualitative research, this approach to interdisciplinarity is called triangulation (see Lynn, 2007a; Schwandt, 2007; Flick, 2006). Much like using multiple compass points to find one's geographic position in a landscape, triangulation is the use of multiple perspectives and methods to achieve the best account of a moral, scientific, and/or social issue. This approach may substantially improve the rigor and communicative competence of the scientific, social, and ethical discourses about wolves. It should fully respect what scientific discourse brings to the table, but at the same time honor what social and ethical discourse brings as well. We might hope that it also serves as a 
model for interdisciplinarity in other arenas and has a positive impact on how we understand humananimal and nature-society relations more generally.

\section{Notes}

1. The terms human science and natural science are commonly used in social theory, qualitative inquiry, and the philosophy of science. The former refers to what others call the behavioral and social sciences, while the latter refers to the physical, biological, and life sciences. In addition to serving as a way to categorize different forms of scientific knowledge, it also implies a more historically and philosophically reflective posture over the theory, methods, and role of science itself (see Ricoeur, 1981).

2. Astute readers may recognize that a similar shift is occurring in the field of cognitive ethology. There is a recognition that many kinds of nonhuman animals think, feel, plan, play, act altruistically and selfishly, have a sense of guilt and wild justice, and transmit cultural traditions. The growth of this theoretical perspective has methodological implications, and represents a turning away from positivist models that frequently misunderstand animals. While using a different language, cognitive ethology is developing its own interpretive theory and qualitative methods. In this sense it is kin to hermeneutic traditions in the human sciences (for examples of such work, see Allen \& Bekoff , 2007; Bekoff , 2005; Bekoff et al., 2002).

3. Hermeneutics is named after Hermes, the Greek god who handled communication between Olympus and the Ecumene-the habitable world of humanity, which for the Greeks was centered on the Mediterranean. Like the coyote, however, Hermes is a trickster, taking pleasure in parsing meaning in ways that lead to misunderstanding. The background idea here is that language is not something we simply use subjectively to describe our feelings or objectively to describe the world. Rather, language is constitutive of how we experience and conceptualize the world around us.

4. For more on the "qualities" and "phenomena" that distinguish the human and natural sciences, as well as the implications this has for causal explanation, qualitative inquiry, and moral reasoning, see Lynn, 2004.

5. When I speak of discourse, I often shift between the singular and plural. This is to denote the scale and specificity of my comments. Thus, I may speak of discourse in general, discourses in particular, or a particular discourse in the singular.

6. There are other theories about discourse that emphasize the ideological nature of "totalizing" discourse (e.g., structuralism), the partiality of all discourse (e.g., poststructuralism) and the distorting tendencies of all discourse (e.g., critical theory). The structuralists and poststructuralists tend to see people as subjects of discourse-i.e., subservient to the discourse(s) that constitute their worldview. Hermeneuticists and critical theorists think otherwise, believing that people have agency - that is, they can be self-determining and are not the pawns of larger social forces. Exercising this agency may not be easy (or possible) for everyone, but it is in the nature of human beings to be agents and interpreters of their own individual and collective lives (for examples of this literature, see Wolf, 2003a, Darier, 1999; Habermas, 1998; Gare, 1995; Habermas, 1993).

7. Words like culture, society, and polity have deep roots in intellectual history and carry overlapping meanings. I have intentionally chosen the term social for its broad resonance across the entire range of the human sciences, arts, and humanities. If people choose to use other words-e.g., culture, politics, community - there is nothing preventing us from translating between these terms and their associated fields of learning and mapping insights from one tradition of scholarship into another. To my mind, it is silly to argue over which disciplinary language is best. Each has empirical and theoretical knowledge to share, and these insights should be appreciated in an interdisciplinary spirit. 
8. I approach ethics and its various discourses from the tradition of practical ethics, perhaps best exemplified by Socrates, Mary Midgley, and Steven Toulmin (Toulmin, 2001, 1986; Midgley, 1993a; Plato, 1987). To paraphrase Socrates, ethics is an exploration of how we ought to live (Plato, 1987). It is an inquiry into moral values that inform-or should inform-our lives, an evaluation of the moral norms embodied in our thought and practice, and a concern for what is good, right, just, or of value in our individual and collective lives. Practical ethicists use moral concepts as rules of thumb to help us grasp the ends and means of life, providing guidelines and guideposts as we strive for what the ancient Greeks termed eudaimonia, a word we translate variously as happiness, well-being, and flourishing (Boss, 1998, 388-389; Maclntyre, 1966, Chapter 7). From the practical ethics perspective, when we engage in ethics, we are not only exploring principles of moral reason; we are also articulating maxims of conduct. Yet we do all this in a manner that takes a diversity of moral insights and contexts into account (see Lynn, 2007a, 2006).

9. Information on the project can be found at www.ornl.gov/sci/techresources/human_genome/research/elsi.shtml.

\section{References}

Allen, C., \& Bekoff, M. (2007). Animal minds, cognitive ethology and ethics. The Journal of Ethics, 11, 299-317.

Anonymous. (2006, Autumn). Wolf center shifts educational focus. Wolf Print, 28, 7-8.

Ball, T. (1988). Transforming political discourse: Political theory and critical conceptual history. New York: Basil Blackwell.

Barnes, T. J., \& Duncan, J. S. (Eds.) (1992). Writing worlds: Discourse, text and metaphor in the representation of landscape. New York: Routledge.

Bekoff, M. (2005). Animal passions and beastly virtues: Reflections on redecorating nature. Philadelphia:Temple University Press.

Bekoff, M., Allen, C., \& Burghardt, G. (Eds.) (2002). The cognitive animal: Empirical and theoretical perspectives on animal cognition. Cambridge: MIT Press.

Bernstein, R. J. (1991). Beyond objectivism and relativism: Science, hermeneutics and praxis. Philadelphia: University of Pennsylvania Press.

Borchardt, A. (1998). The silver wolf. New York: Ballantine.

Boss, J. A. (1998). Ethics for life: An interdisciplinary and multicultural introduction. Mountain View, CA: Mayfield.

Brandenburg, J. (1990). White wolf: Living with an Arctic legend. Minocqua, MN: Northwood Press.

Bruns, G. L. (1992). Hermeneutics ancient and modern. New Haven, CT: Yale University Press.

Busch, R. (1994). Wolf songs: The classic collection of writing about wolves. San Francisco: Sierra Club Books.

Chalmers, A. (1999). What is this thing called science? An assessment of the nature and status of science and its methods (3rd ed.). London: Open University Press.

Coleman, J. (2004). Vicious: Wolves and men in America. New Haven, CT: Yale University Press.

Darier, E. (1999). Discourses of the environment. New York: Blackwell.

Decker, D. J., Brown, T. L., \& Siemer, W. F. (Eds.). (2001). Human dimensions of wildlife management in North America. Bethesda, MD: Wildlife Society.

Denzin, N. K., \& Lincoln, Y. S. (2000). The discipline and practice of qualitative research. In N. K. Denzin \& Y. S. Lincoln, (Eds.), Handbook of Qualitative Research (2nd ed., pp. 1-28). Thousand Oaks, CA: Sage.

Douglas, A. (1992). The beast within: A history of the werewolf. London: Chapmans. 
Dunlap, T. (1988). Saving America's wildlife: Ecology and the American mind, 1850-1990. Princeton: Princeton University Press.

Dutcher, J., Dutcher, J., (with Manfull, J.). (2002). Wolves at our door: The extraordinary story of the couple who lived with wolves. New York: Pocket Books.

Emel, J. (1995). Are you man enough, big and bad enough: Ecofeminism and wolf eradication in the U.S. Environment and Planning D: Society and Space 13, 707-734.

Evans, N. (1998). The loop: A novel. New York: Dell.

Fischer, F., \& Forester, J. (1996). The argumentative turn in policy analysis and planning. Durham: Duke University Press.

Flader, S. L. (1994). Thinking like a mountain: Aldo Leopold and the evolution of an ecological attitude toward deer, wolves and forests. Madison: University of Wisconsin Press.

Flick, U. 2006. An introduction to qualitative research (3rd ed.). Thousand Oaks: Sage.

Fox, M. W. (2001). Bringing life to ethics: Global bioethics for a humane society. Albany: State University of New York Press.

Gadamer, H. G. (1993). Truth and method (2nd ed.). New York: Continuum.

Gare, A. E. (1995). Postmodernism and the environmental crisis. New York: Routledge.

Glacken, C. J. (1967). Traces on the Rhodian shore: Nature and culture in Western thought from ancient times to the end of the eighteenth century. Berkeley: University of California Press.

Gray, G. G. (1993). Wildlife and people: The human dimensions of wildlife ecology. Chicago: University of Illinois Press.

Habermas, J. (1993). Justification and application: Remarks on discourse ethics (Ciaran Cronin, Ed.). Cambridge: MIT Press.

— (1998). Between facts and norms: Contributions to a discourse theory of law and democracy. Cambridge: MIT Press.

Hesse-Biber, S. N., \& Leavy, P. (2005). The practice of qualitative research: A primer. Thousand Oaks: Sage.

Hirsch, E. D. 1967. Validity in interpretation. New Haven: Yale University Press.

Hirschman, A. O. 1987. The search for paradigms as a hindrance to understanding. In P. Rabinow \& W. M. Sullivan (Eds.), Interpretive social science: A second look (pp. 177-194). Berkeley: University of California Press.

Jickling, B., \& Paquet, P. C. (2005, Fall). Wolf stories: Reflections on science, ethics and epistemology. Environmental Ethics 27, 115-135.

Katz, E. (2000). Another look at restoration: Technology and artificial nature. In P. H. Gobster \& R. B. Hull (Eds.), Restoring nature: Perspectives from the social sciences and humanities (pp. 37-48). Washington DC: Island Press.

Kelly, M. (Ed.). (1990). Hermeneutics and critical theory in ethics and politics. Cambridge, MA: MIT Press.

Kuhn, T. S. (1970). The structure of scientific revolutions (2nd ed). Chicago: University of Chicago Press.

Kyle, C. J., Johnson, A. R., Patterson, B. R., Wilson, P. J., Shami, K., Grewal, S. K., \& White, B. N. (2006). Genetic nature of Eastern wolves: Past, present and future. Conservation Genetics 7(2), 273-287.

Lavigne, D. (Ed.). (2006). Gaining ground: In pursuit of ecological sustainability. Limerick, Ireland: University of Limerick Press.

Leopold, A. (1968). A Sand County almanac: And sketches here and there. Oxford: Oxford University Press.

Lindberg, D. C. (1992). The beginnings of Western science: The European scientific tradition in philosophical, religious, and institutional context, 600 B.C. to A.D. 1450. Chicago: University of Chicago Press.

Livingstone, D. N. (1992). The geographical tradition: Episodes in the history of a contested discipline. Oxford: Basil Blackwell. 
Lopez, B. H. (1978). Of wolves and men. New York: Scribners.

Lynn, W. S. (1998a). Animals, ethics and geography. In J. Wolch \& J. Emel (Eds.), Animal geographies:

Place, politics and identity in the nature-culture borderlands (pp. 280-298). London: Verso.

(1998b). Contested moralities: Animals and moral value in the Dear/Symanski debate. Ethics, Place and Environment 1(2), 223-242.

(2002). Canis lupus cosmopolis: Wolves in a cosmopolitan worldview. Worldviews 6(3), 300-327.

(2004). The quality of ethics: Moral causation in the interdisciplinary science of geography. In R. Lee

\& D. M. Smith (Eds.), Geographies and moralities: International perspectives on justice, development and place (pp. 231-244). London: Routledge.

(2005). Wolves are indicators of moral health. Ethos: The practical ethics blog, June 21, www.practicalethics.net.

(2006). Between science and ethics: What science and the scientific method can and cannot contribute to conservation and sustainability. In D. Lavigne (Ed.), Gaining ground: In pursuit of ecological sustainability (pp. 191-205). Limerick, Ireland: University of Limerick.

— (2007a). Practical ethics and human-animal relations. In M. Bekoff (Ed.), Encyclopedia of humananimal relationships (pp. 790-797). Westport: Greenwood Press.

(2007b). Wolf recovery. In M. Bekoff (Ed.), Encyclopedia of human-animal relationships, (pp. 812819). Westport: Greenwood Press.

Macintyre, A. (1966). A short history of ethics. New York: MacMillan.

Manfredo, M. J., Vaske, J. J., Brown, P. J., Decker, D. J., \& Duke, E. A. (Eds.). (2009). Wildlife and society: The science of human dimensions. Washington DC: Island Press.

Matteson, M. Y. (1996). Wolf re-story-ation: The importance of myth and values in ecological restoration efforts. In Defenders of Wildlife (Ed.), Wolves of America, Conference Proceedings (pp. 218-222). Washington DC: Defenders of Wildlife.

McIntyre, R. (1993). A society of wolves: National parks and the battle over the wolf (Rev. ed.). Stillwater, MN: Voyageur Press.

_ (Ed.). (1996). War against the wolf: America's campaign to exterminate the wolf. Stillwater, MN: Voyageur Press.

Midgley, M. (1993a). Can't we make moral judgements? New York: St. Martin's Press.

— (1993b). The origin of ethics. In Peter Singer (Ed.), A companion to ethics (pp. 3-13). Cambridge: Basil Blackwell.

- (1995). The moral primate: Humans, freedom and morality. New York: Routledge.

- (1998). Animals and why they matter. Athens: University of Georgia Press.

— (2001). The problem of living with wildness. In V. A. Sharpe, S. Donnelley, \& B. Norton (Eds.), Wolves and human communities: Biology, politics, and ethics (pp. 179-190). Washington, DC: Island Press.

Moyer, Bill (with Macalister, J., Finley, M. L., \& Soifer, S.) (Eds.). (2001). Doing democracy: The MAP model for organizing social movements. Gabriola Island, BC: New Society Publishers.

Mueller-Vollmer, K. (1989). The hermeneutics reader: Texts of the German tradition from the Enlightenment to the present. New York: Continuum.

Naess, A. (1974, Summer). Self-realization in mixed communities of humans, bears, sheep, and wolves. Inquiry 22, 231-241.

Nie, M. A. (2003). Beyond wolves: The politics of wolf recovery and management. Minneapolis: University of Minnesota Press.

Plato. (1987). The Republic. (2nd ed.) (Desmond Lee, Trans.). New York: Penguin.

Rachels, J. (1986). The elements of moral philosophy. New York: Random House.

Rawson, T. (2001). Changing tracks: Predators and politics in Mt. McKinley National Park. Fairbanks: University of Alaska Press. 
Ricoeur, P. (1977). The model of the text: Meaningful action considered as a text. In F. Dallmayr \& T. A. McCarthy (Eds.), Understanding social inquiry (pp. 316-344). Notre Dame: University of Notre Dame Press.

— (1981). Hermeneutics and the human sciences. Cambridge: Cambridge University Press.

— (1991). From text to action: Essays in hermeneutics. Chicago: Northwestern University Press.

- (1996). The hermeneutics of action. Chicago: Northwestern University Press.

Robinson, M. (2005). Predatory bureaucracy: The extermination of wolves and the transformation of the West. Boulder: University Press of Colorado.

Roe, E. (1994). Narrative policy analysis: Theory and practice. Durham: Duke University Press.

Rolston, H., III. (1988). Environmental ethics: Duties to and values in the natural world. Philadelphia: Temple University Press.

Rorty, R. (1979). Philosophy and the mirror of nature. Princeton: Princeton University Press.

Schwandt, T. A. (2007). Dictionary of qualitative inquiry (3rd ed.). Thousand Oaks: Sage.

Sharpe, V. A., Strachan, D., and Norton, B. (Eds.). (2001). Wolves and human communities: Biology, politics, and ethics. Washington DC: Island Press.

Shogren, E. (2006). Orphaned wolves lost in Idaho. Morning Edition, NPR, July 7, 2006.

Sibley, M. Q. (1970). Political ideas and ideologies: A history of political thought. New York: Harper \& Row.

Smith, D., Petersen, R., \& Houston, D. (2003). Yellowstone after wolves. BioScience 53(4), 330-340.

Toulmin, S. (1986). The place of reason in ethics. Chicago: University of Chicago Press.

- (2001). Return to reason. Cambridge: Harvard University Press.

Wachterhauser, B. R. (Ed.). (1994). Hermeneutics and truth. Evanston: Northwestern University Press.

Westley, F., \& Miller, P. (Eds.). (2003). Experiments in consilience: Integrating social and scientific responses to save endangered species. Washington DC: Island Press.

Wilson, E. O. (1998). Consilience: The unity of knowledge. New York: Alfred A. Knopf.

Wolf, C. (2003a). Animal rites: American culture, the discourse of species, and posthuman theory. Chicago: University of Chicago Press.

- (Ed.). (2003b). Zoontologies: the question of the animal. Minneapolis: University of Minnesota Press.

Worster, D. (1985). Nature's economy: A history of ecological ideas. (2nd ed.). Cambridge: Cambridge University Press.

Yanow, D. (1999). Conducting interpretive policy analysis. Thousand Oaks: Sage. 